STUDIA EDUKACYJNE NR 31/2014

\author{
MACIEJ MUSKAŁA \\ Uniwersytet im. Adama Mickiewicza \\ $w$ Poznaniu
}

\title{
ZNACZENIE GOTOWOŚCI DO ZMIANY W PROCESIE RESOCJALIZACJI
}

\begin{abstract}
Muskała Maciej, Znaczenie gotowości do zmiany w procesie resocjalizacji [The Importance of Readiness for Change in the Process of Social Rehabilitation]. Studia Edukacyjne nr 31, 2014, Poznań 2014, pp. 219-232. Adam Mickiewicz University Press. ISBN 978-83-232-2781-6. ISSN 1233-6688

The text focuses on the problems of motivation to change socially unadjusted individuals. It not only presents the issues of placement, importance and consequences of involvement or lack of involvement in the process of rehabilitation, but also adds the issue of readiness to change, which appears to be overriding and defining specific conditions of engagement into a therapy or other forms of interventions.
\end{abstract}

Key words: readiness, motivation, rehabilitation

\section{Wprowadzenie}

Najlepsze programy oddziaływań resocjalizacyjnych, odwołujące się do najbardziej aktualnych założeń teoretycznych w połączeniu z profesjonalną wdrażającą je kadrą, mogą okazać się mało skuteczne $\mathrm{w}$ zetknięciu z tak powszechną wśród osób niedostosowanych społecznie niechęcią czy niską motywacją do zmiany. A właśnie ta niska motywacja, czy wręcz jej brak i to nawet nie do zmiany, co do samego uczestnictwa w procesie oddziaływań, jest cechą endemiczną tak $w$ przypadku dorosłych, jak i nieletnich niedostosowanych społecznie, zwłaszcza przebywających w placówkach izolacyjnych. Co dla praktyka, wychowawcy, funkcjonariusza liniowego jest oczywiste, swoisty opór czy niechęć do uczestnictwa w procesie resocjalizacji, „gdyż pobyt w placówkach postrzegany jest przez nich przede wszystkim 
jako przymus i represja" 1 , bywa zwłaszcza przez ustawodawcę błędnie interpretowany. Stąd, czynienie z tego faktu podstaw do wyciągania daleko idących konsekwencji, jak chociażby wyciąganie negatywnych konsekwencji za odmowę uczestnictwa $\mathrm{w}$ programie, należy uznać za przesadne ${ }^{2}$. Oczywiste jest, co potwierdzają liczne wypowiedzi tak praktyków, teoretyków, jak i samych więźniów, że tylko od samego skazanego zależy, czy podjęte (ewentualnie) oddziaływania resocjalizacyjne przyniosą pożądany efekt.

Zatem, rozbudzanie motywacji czy gotowości do zmiany (o różnicach $\mathrm{w}$ rozumieniu tych dwu pojęć poniżej) jawi się jako nieodłączny element skutecznego oddziaływania resocjalizacyjnego.

\section{Motywacja}

Tradycyjnie motywację postrzegano jako cechę osobowości, lecz takie ujęcie było zarówno restrykcyjne, jak i uproszczone. Perspektywa, w której motywacja była rozumiana jako pewien stan czy współczynnik stanu (tzn. zmotywowany lub bez motywacji) nie obejmowała czynników wpływających na chęć osoby do zmiany swojego zachowania. Pogląd ten został zastąpiony w ostatnich latach takim, który podkreśla złożoność zmiany.

Dlatego też pojęcie motywu, a nawet motywacji jako zjawiska jednorodnego ustępuje (...) miejsca terminowi „procesy motywacyjne”, i to używanemu właśnie w liczbie mnogiej, co podkreśla jego poligeniczny charakter ${ }^{3}$.

Ten interakcyjny model zakłada, że czynniki wewnętrzne i zewnętrzne wpływają na proces zmiany. $Z$ tej perspektywy motywacja postrzegana jest jako interakcyjny i interpersonalny proces, na który może mieć wpływ pozytywne działanie praktyka. W tym kontekście motywacja jest dynamiczna, a zatem konieczne jest, aby terapeuta motywował w kontekście resocjaliza-

${ }^{1}$ L. Pytka, Pedagogika resocjalizująca, [w:] Encyklopedia pedagogiczna, red. W. Pomykało, Warszawa 1997; J. McGuire, Motivation for what? Effective programmes for motivated offenders, [w:] Motivating Offenders to Change, a Guide to Enhancing Engagement in Therapy, red. M. McMurran, Chichester 2002, s. 157.

2 Jako przykład takiego podejścia niech posłużą, analizowane wcześniej, regulacje przyjęte w Rozporządzeniu Ministra Sprawiedliwości z 20 lipca 2009 r., zmieniającego rozporządzenie w sprawie zakładów poprawczych i schronisk dla nieletnich - DzU z 2009, nr 119, poz. 996, gdzie w §1, pkt 10 można przeczytać, że jedną z podstaw do umieszczenia nieletniego w tego typu placówce jest odmowa uczestniczenia w procesie wychowania, edukacji bądź terapii. Szerzej na ten temat i innych kontrowersyjnych zapisów z tego Rozporządzenia zob. M. Muskała, Zakłady poprawcze readaptacyjne - nowa szansa readaptacji? Probacja, 2011, 2, s. 32-41.

${ }^{3}$ J.K. Gierowski, T. Jaśkiewicz-Obydzińska, M. Najda, Psychologia w postępowaniu karnym, Warszawa 2008, s. 337. 
cyjnym przestępcę, czy szerzej - niedostosowanego społecznie. Operacyjnie motywacja może być zdefiniowana jako „prawdopodobieństwo, że dana osoba rozpocznie, będzie kontynuować i stosować się do konkretnej strategii" ${ }^{4}$.

We współczesnej literaturze dotyczącej motywacji ${ }^{5}$ istnieje kilka jej teoretycznych modeli. Najbardziej wpływowy został opracowany przez J.O. Prochaskę i C.C. DiClemente transteoretyczny model zmiany (transtheoretical model of change). Zakłada on, że podczas rozwiązywania problemu ludzie przechodzą przez możliwe do zidentyfikowania cztery etapy zmiany: prekontemplacyjny (przedrefleksyjny) (precontemplation), kontemplacyjny (refleksji) (contemplation), działania (action), utrzymania (maintenance) ${ }^{6} . \mathrm{Na}$ etapie pierwszym osoba nawet nie rozważa możliwości zmiany; jest niezmotywowana i nieświadoma problemu. Osoby na tym etapie zazwyczaj postrzegają, że są zmuszane do terapii, aby zaspokoić czyjeś potrzeby. Etap rozważania (kontemplacyjny) charakteryzuje się ambiwalencją, innymi słowy: osoby mogą równocześnie lub naprzemiennie brać pod uwagę i odrzucać powody do zmiany. Osoby na etapie działania podjęły zobowiązanie do zmiany i angażują się w działania, żeby tę zmianę spowodować. Zazwyczaj na tym etapie są one zaangażowane $\mathrm{w}$ terapię. Wreszcie, osoby $\mathrm{w}$ fazie utrzymania pracują, aby utrzymać znaczące zmiany, jakich dokonali i aktywnie działają w celu zapobiegania nawrotom ${ }^{7}$. Zdaniem twórców tej koncepcji, na każdym z tych etapów można motywować (przestępców) do zmiany stylu życia. Proces taki przechodzi przez pięć faz: 1. Recruitment, 2. Retention, 3. Progress, 4. Process, 5. Outcomes, a skuteczność warunkowana jest znajomością zasad i procesu zmiany, które mogą stymulować postęp $p^{8}$. Można jednak spotkać w literaturze pogląd, że transteoretyczny model zmiany J.O. Prochaski i C.C. DiClemente nie uwzględnia dodatkowych zysków $\mathrm{z}$ zaangażowania $\mathrm{w}$ terapię ${ }^{9}$.

${ }^{4}$ R. Serin, S. Kennedy, Treatment Readiness and Responsivity: Contributing to Effective Correctional Programming, Correctional Service of Canada, 1997, s. 9-10.

${ }^{5}$ D. Doliński, W. Łukaszewski, Typy motywacji, [w:] Psychologia. Podręcznik akademicki, t. I, red. J. Strelau, Gdańsk 2000, zwłaszcza s. 469-475; W. Łukaszewski, Motywacja w najważniejszych systemach teoretycznych, [w:] Psychologia, zwłaszcza s. 433-435; G. WieczorkowskaNejtardt, Inteligencja motywacyjna, Warszawa 1998, zwłaszcza s. 13-23; R.E. Franken, Psychologia motywacji, Gdańsk 2005; F. Rheinberg, Psychologia motywacji, Kraków 2006.

${ }^{6}$ Obecnie mówi się o jeszcze dwóch etapach: przygotowania, występującego jako trzeci, i rozwiązania, ostatni jako ostatecznego celu każdej zmiany

7 R. Serin, S. Kennedy, Treatment Readiness, s. 12.

8 J.O. Prochaska, D.A. Levesque, Enhancing Motivation of Offenders at Each Stage of Change and Phase of Therapy, [w:] Motivating Offenders to Change, A Guide to Enhancing Engagement in Therapy, red. M. McMurran, Chichester 2002, s. 64-66.

${ }^{9} \mathrm{~K}$. Howells, A. Day, Readiness for anger management: clinical and theoretical issues, Clinical Psychology Review, 2003, 23 (2), s. 328. 
Istotne może się tu okazać rozróżnienie pomiędzy motywacją wewnętrzną a zewnętrzną, jak to ma miejsce $\mathrm{w}$ teorii samookreślenia (selfdetermination theory - STD) E.L. Deci i R.M. Ryana.

Sugeruje ona, że ludzka motywacja powinna być rozważana w kontekście wrodzonych psychologicznych potrzeb kompetencji, autonomii i relacji. $\mathrm{W}$ ich terminologii pojęcie potrzeb określa treść motywacji (...). Deci i Ryan twierdzą, że społeczne konteksty, które utrudniają spełnienie tych potrzeb są związane z gorszą motywacją, wydajnością i samopoczuciem. W modelu samookreślenia STD, Deci i Ryan sugerują kontinuum od zewnętrznej do wewnętrznej motywacji, gdzie zaspokajanie potrzeb autonomii, kompetencji i relacji ma najważniejszy wpływ na motywację wewnętrzną ${ }^{10}$.

Prowadzi to ich do rozróżnienia czterech postaci motywacji zewnętrznej, ze względu na stopień autonomii jednostki w kształtowaniu motywacji.

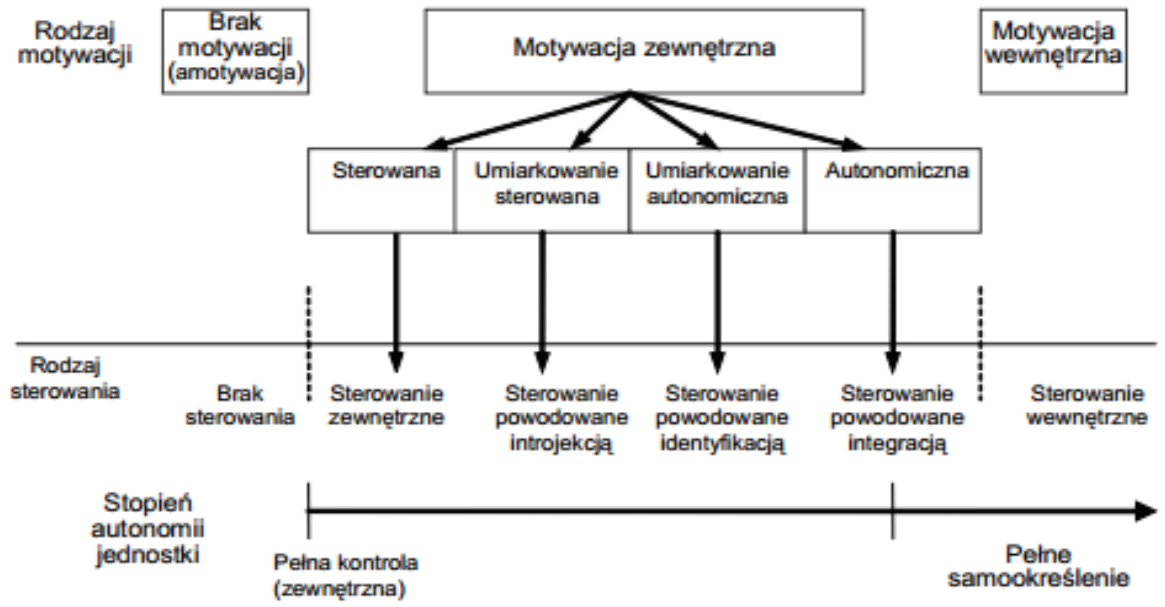

Ryc. 1. Rodzaje motywacji według self-determination theory E.L. Deci i R.M. Ryana

(źródło: I. Rzońca, Motywacja do aktywnego uczestnictwa w grze kierowniczej - wyniki badań ankietowych, Studia i Materiały, 2007, 25, s. 170)

Ostatni teoretyczny model motywacji, co może okazać się szczególnie cenne $\mathrm{w}$ odniesieniu do oddziaływań resocjalizacyjnych, odwołuje się do modelu oceny ryzyka R-N-R (zaprezentowanej w innym miejscu) i do trzeciej obok "ryzyka” i „potrzeb” podstawowej zasady, a mianowicie zasady „reaktywności”. Koncentruje uwagę na kliencie i cechach programu, które wpływają na możliwości nauki danej osoby w sytuacji terapeutycznej. 
Z tego punktu widzenia terapia jest doświadczeniem edukacyjnym, a czynniki przeszkadzające lub ułatwiające terapeutyczną „naukę" mogą być nazwane czynnikami reaktywności ${ }^{11}$. Indywidualne cechy, które zakłócają lub ułatwiają "naukę", można podzielić na wewnętrzne i zewnętrzne czynniki reaktywności. Czynniki wewnętrzne odnoszą się do cech indywidualnych osób: motywacji, cech osobowości (jak np. psychopatia, niepokój, depresja, choroby psychiczne, poczucie własnej wartości, złe umiejętności społeczne); kognitywno-intelektualnych deficytów (np. niska inteligencja, konkretne ukierunkowane myślenie, niedostateczne umiejętności rozwiązywania problemów, słabe umiejętności werbalne) i innych zmiennych demograficznych (jak: wiek, płeć, rasa, pochodzenie etniczne). Czynniki zewnętrzne odnoszą się do terapeuty i właściwości otoczenia' ${ }^{12}$.

R. Serin zidentyfikował 11 elementów gotowości z perspektywy responsywności: (1) uznanie problemu (problem recognition), (2) ustalanie celów (goal setting), (3) motywacja (motivation), (4) samoocena (self-appraisal), (5) oczekiwania (expectations), (6) behawioralna spójność (behavioural consistency), (7) poglądy na terapię (views about treatment), (8) poczucie własnej skuteczności (self-efficacy), (9), dysonans (dissonance), (10) zewnętrzne wsparcie (external supports) i (11) reakcje afektywne (affective component) $)^{13}$.

\section{Wieloczynnikowy Model Gotowości Przestępcy}

Coraz częściej podkreśla się w literaturze konieczność rozróżnienia motywacji od reaktywności i gotowości. Właśnie to ostatnie pojęcie określane jest jako nadrzędne, zawierające oba powyższe i określające specyficzne warunki decydujące o zaangażowaniu się w terapię. Zdaniem K. Howellsa i A. Daya,

Pojęcie gotowości można ogólnie zdefiniować jako obecność cech (stanów lub predyspozycji) albo wewnątrz osoby lub w sytuacji terapeutycznej, które mogą wpierać zaangażowanie w terapię, i które w ten sposób mogą poprawić terapeutyczną zmianę ${ }^{14}$.

Zaprezentowany na rycinie 2, a zaproponowany przez T. Warda i współautorów Wieloczynnikowy Model Gotowości Przestępcy (Multifactor

11 Tamże, s. 330.

12 R. Serin, S. Kennedy, Treatment Readiness, s. 14.

${ }_{13} \mathrm{R}$. Serin, Treatment responsivity, intervention and reintegration: a conceptual model, Forum on Corrections Research, 1998, 10 (1), s. 30.

${ }^{14} \mathrm{~K}$. Howells, A. Day, Readiness for treatment in high risk offenders with personality disorders, Psychology, Crime \& Law, 2007, 13 (1), s. 49. 
Offender Readiness Model) zakłada nie tylko jej zależność od czynników wewnętrznych i zewnętrznych, ale także ich wzajemne oddziaływanie na siebie. Kolejne istotne założenie tej koncepcji polega na tym, że zaangażowanie jest koniecznym, ale niewystarczającym warunkiem do zmiany w potrzebach kryminogennych.
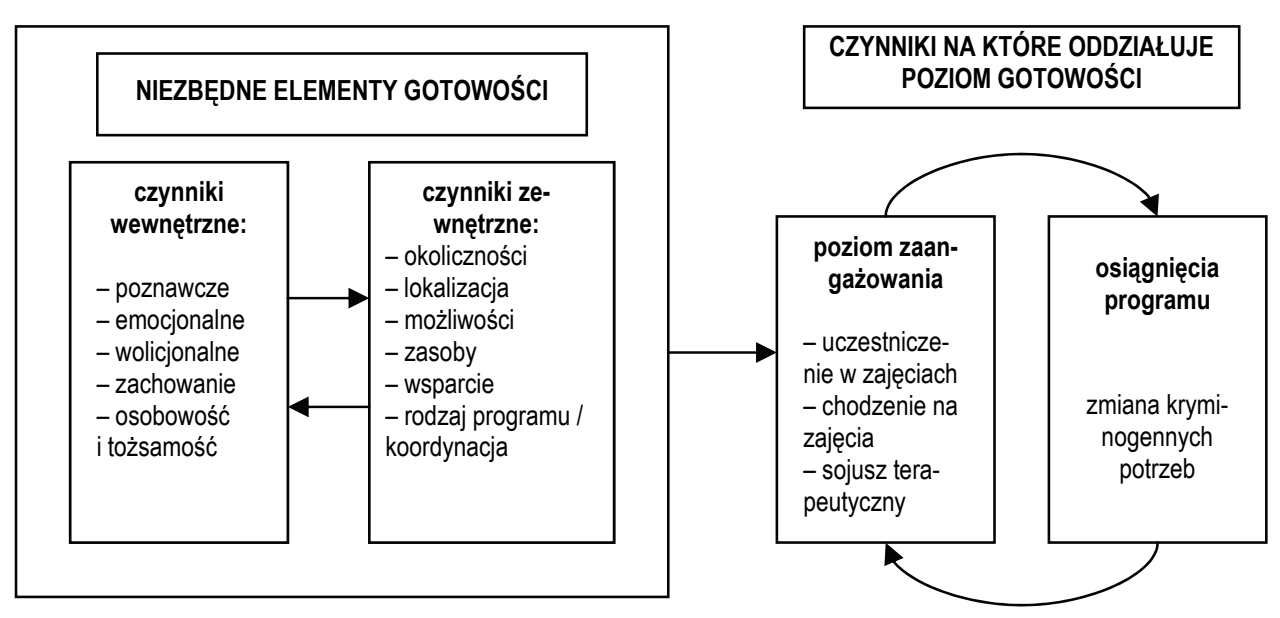

Ryc. 2. Wieloczynnikowy Model Gotowości Przestępcy

(Multifactor Offender Readiness Model)

(źródło: T. Ward, A. Day, K. Howells, A. Birgden, The multifactor offender readiness model, Aggression and Violent Behavior, 2004, 9 (6), s. 650)

\section{Wewnętrzne czynniki gotowości (internal readiness factors)}

Poznawcze (cognitive) zmienne kognitywne. Obejmują nastawienia, przekonania i wzorce myślenia, które mogą osłabić zaangażowanie, np. wrogie przekonania i atrybucje, niski poziom zaufania, jak również specyficzne oczekiwania samego oddziaływania oraz jego wyniku. Inne ważne procesy poznawcze mogą obejmować percepcję i przekonania dotyczące personelu, jak i samych programów oferowanych w ramach systemu wymiaru sprawiedliwości. Ważna jest wiara we własną skuteczność (selfefficacy), podobnie jak przekonania dotyczące zmiany.

Emocjonalne (emotionaVaffective). K. Howells i A. Day zwracają uwagę, że na gotowość wpływają trzy aspekty emocjonalności:

zdolności do osiągnięcia i doświadczenia stanów emocjonalnych, zdolność do wyrażania emocji i zdolność do refleksji na temat stanów emocjonalnych. (...) Niezależnie 
od przyczyny, nieumiejętność doświadczania, wyrażania i refleksji na temat emocji jest przeszkodą dla gotowości do wielu programów terapeutycznych wymagających ujawnienia stanów emocjonalnych i ich roli jako poprzedników poważnej przestępczości15.

W warunkach placówek resocjalizacyjnych pewną rolę będą odgrywały tu również inne czynniki, które można określić jako „instytucjonalne”, ale jako czynniki zewnętrzne zostaną omówione w dalszej części. W analizie czynnika emocjonalnego gotowości przydatne jest rozróżnienie pomiędzy ogólnymi stanami afektywnymi i emocjami a afektywnymi i emocjonalnymi reakcjami uzależnionymi od celu ${ }^{16}$. Przestępcy niebezpieczni, zaliczani w modelu szacowania ryzyka do grup wysokiego ryzyka, różnią się w zakresie, w jakim ich przestępcze zachowanie wywołuje reakcje winy, wstydu i wyrzutów sumienia $\mathrm{w}$ porównaniu $\mathrm{z}$ innymi przestępcami. $\mathrm{Z}$ definicji, „psychopatyczni” przestępcy będą charakteryzowali się brakiem takich emocji, co określa się jako równoznaczne z brakiem gotowości, podczas gdy inne osoby z zaburzeniami osobowości (zaburzenia borderline) mogą wykazywać skrajnie silne emocjonalne reakcje tego rodzaju. Znaczenie problematyki winy i wstydu w oddziaływaniach resocjalizacyjnych, dostrzeżone i szeroko analizowane, tu rozpatrywane są tylko w kontekście gotowości do zmiany. W odniesieniu do tego zagadnienia podkreśla się, że zachowania związane ze wstydem, np. unikanie innych, mogą prowadzić do obniżenia poziomu gotowości, natomiast poczucie winy poprawia ją. Zatem, o postępie mówi się w sytuacji: „odejście od wstydu w kierunku winy i ze względu na inne tendencje do działania związane $z$ tymi emocjami (chowanie się kontra przeproszenie i zadośćuczynienie)"17.

Behawioralne (behaviovioural factors). Są to czynniki związane z zachowaniem, wymagane dla skutecznego zaangażowania się $\mathrm{w}$ konkretne oddziaływanie. Mogą obejmować zdolność do dokładnej oceny czyjegoś obecnego zachowania, uwarunkowane normami kulturowymi - rozpoznawania problemu, szukania pomocy w przypadku problemów, tworzenia relacji i posiadania podstawowych kompetencji społecznych i kognitywnych, których wymaga zaangażowanie się w poszczególny program (umiejętność opisywania i mówienia o zachowaniach, myślach i uczuciach, pewność siebie w pracy, w grupie, odgrywanie ról).

${ }^{15} \mathrm{~K}$. Howells, A. Day, Affective states in violent offenders and their relationship to readiness for treatment, International Journal of Offender Therapy and Comparative Criminology, 2006, 50 (2), s. 179.

${ }^{16}$ K. Howells, A. Day, Readiness for treatment, s. 50.

17 Tamże. 
Wolicjonalne (volitionals factors). Dotyczą intencji osiągnięcia danych celów, czyli to co tradycyjnie określa się mianem motywacji. Gotowość wymaga świadomości celów, muszą one być dla sprawcy/przestępcy/klienta zgodne z jawnymi, jak i ukrytymi celami programu. Brak tej zgodności skutkuje niskim poziomem gotowości.

Osobowościowe (personal identity factors). Zawierają najważniejszy element wartości i przekonań danej osoby. Znaczenie dla gotowości ma to, żeby tożsamość danej osoby umożliwiała zmianę w kierunku wymaganym przez program ${ }^{18}$.

\section{Zewnętrze czynniki gotowości (external readiness factors)}

Okoliczności (circumstance factors). Czynnik ten odnosi się do osobistych sytuacji przestępcy i stopnia, $\mathrm{w}$ jakim ułatwiają one zaangażowanie $\mathrm{w}$ terapię. Najważniejszą kwestię stanowi tu ustalenie, czy terapia jest nakazana czy dobrowolna, a zatem - czy jest kwestią indywidualnego wyboru czy presji społecznej. Oczywiście, terapia pod presją społeczną może skutkować niechęcią i brakiem zaangażowania. Zakres, w jakim obowiązkowa, przymusowa, czy nakazana terapia wpływa na gotowość, a następnie na wyniki jest trudny do określenia częściowo dlatego, że definicja tego, co stanowi „dobrowolne" jest problematyczna, co zostało zasygnalizowane wcześniej. Warto może w tym miejscu przypomnieć tylko, że na przymus należy patrzeć nie tylko w kategoriach statusu prawnego, czy presji prawnej do udziału $\mathrm{w}$ danym programie, ale - $\mathrm{i}$ kto wie czy nie przede wszystkim z punktu widzenia postrzegania go przez przestępcę.

Lokalizacja (location factors). Lokalizacja przestępcy/miejsca, w którym odbywa się oddziaływanie jest ważna dla kwestii gotowości. Krytycznym zagadnieniem jest fakt, czy odbywa się ono w instytucji penitencjarnej, w ramach wykonywania kary pozbawienia wolności, czy w sytuacji oddziaływań wolnościowych. Będzie tu wchodziło $w$ grę zarówno środowisko więzienne - o którym więcej przy omawianiu kolejnego czynnika - jak i charakter relacji pomiędzy przestępcą a wychowawcą, terapeutą. Relacja ta w warunkach izolacji penitencjarnej ma odmienny, zmodyfikowany charakter w porównaniu z jej postacią tradycyjną. „Można ją przedstawić w formie trójkąta, w którym obok terapeuty i skazanego występują jeszcze inne podmioty zainteresowane przebiegiem i wynikami terapii"19. Jak uważają

18 T. Ward, A. Day, K. Howells, A. Birgden, The multifactor, s. 660.

${ }_{19}$ A. Majcherczyk, Specyfika terapii uzależnienia od środków psychoaktywnych w zakładach karnych, Alkoholizm i Narkomania, 2007, 20, 3, s. 324. 
J.I.D. Ginsburg, R.E. Mann, F. Rotgers i J.R. Weekes, można stwierdzić, że „W wielu przypadkach klientem nie jest przestępca - może on, owszem, być odbiorcą interwencji, lecz klientem często jest sąd, rząd państwa czy, najogólniej, społeczeństwo" 20 . Konsekwencją trójbiegunowej relacji są ograniczenia organizacyjne, jak i etyczne, wśród których ograniczenie poufności wysuwa się na plan pierwszy.

Możliwości (opportunity factors). Czynniki te odnoszą się do dostępności terapii i programów w ramach instytucji, w której znajduje się przestępca. Stopien, $w$ jakim osoba jest gotowa na terapię rozciąga się poza jej kompetencje i stany psychologiczne. Istotne jest, czy w danej instytucji osiągalne są wymagane, skuteczne programy. Czynniki środowiskowe także odgrywają ważną rolę w kształtowaniu zachowań, a więzienne środowisko społeczne stanowi główny czynnik, który wpłynie na gotowość do terapii, jak i określi zakres, w jakim korzyści z terapii są podtrzymywane i uogólnione.

Etap kary również odgrywa ważną rolę w tym, czy przestępcy dostrzegą możliwość uczestniczenia $w$ terapii. Osoby, które są już bliskie uwolnienia z więzienia mogą nie mieć wystarczająco czasu na ukończenie programu, więc mogą nie mieć takiej propozycji, lub odwrotnie - mogą być bardziej gotowi do uczestniczenia, kiedy zbliża się możliwość wcześniejszego zwolnienia warunkowego. (...) Osoby rozpoczynające długą karę mogą czuć, że będą miały wiele możliwości w trakcie wyroku i dlatego mogą nie czuć bezpośredniej presji do udziału²1.

Zasoby (resource factors). Możliwość realizacji programów terapeutycznych uwarunkowana jest jeszcze dwoma kwestiami. Po pierwsze, obecnością wykwalifikowanego i wyszkolonego personelu, od którego wymaga się posiadania odpowiedniej wiedzy technicznej, doświadczenia w pracy z daną populacją, umiejętności motywowania przestępców oraz kulturę instytucjonalną, która wspiera resocjalizację. Po drugie, zasobów fizycznych koniecznych do przeprowadzenia programu. O ile jednak z tym pierwszym służba więzienna radzi sobie coraz lepiej22, to kwestia druga pozostawia wiele do życzenia. Poruszone powyżej problemy są o tyle istotne, że optymalizacja zasobów (resourcing) programów również została uznana za istotną kwestię w utrzymaniu ciągłości programu.

${ }^{20}$ J.I.D. Ginsburg, R.E. Mann, F. Rotgers, J.R. Weekes, Wywiad motywujacy z populacjami przestępczymi w trakcie odbywania kary lub dozoru, [w:] Wywiad motywujący. Jak przygotować ludzi do zmiany, red. W.R. Miller, S. Rollnick, Kraków 2010, s. 420.

${ }^{21}$ T. Ward, A. Day, K. Howells, A. Birgden, The multifactor, s. 663.

$22 \mathrm{~W}$ ciągu minionego 10-lecia liczebność kadry penitencjarnej znacznie się zwiększyła: z 23447 funkcjonariuszy i pracowników w roku 2002 do 29532 w roku 2012. Również w zakresie poziomu wykształcenia widać znaczący postęp. W roku 2012 już 51,5\% kadry legitymowało się wyższym wykształceniem. 
W polskich zakładach karnych na oddziałach terapeutycznych i poza nimi, zgodnie z Zarządzeniem nr 02/04 Dyrektora Generalnego Służby Więziennej23, tworzy się i prowadzi autorskie programy resocjalizacyjnoterapeutyczne. $Z$ dostępnych danych wynika, że w 2004 roku było ich ponad 550 (34 na oddziałach terapeutycznych dla skazanych uzależnionych, 22 na oddziałach terapeutycznych dla skazanych z niepsychotycznymi zaburzeniami psychicznymi lub upośledzonych umysłowo, 496 poza oddziałami terapeutycznymi). Mimo tak wydawałoby się znacznej liczby, wiele wskazuje na to, że istniejące programy resocjalizacyjne często są przeciążone, a większość więźniów nie bierze udziału w żadnym. Z szacunkowych wyliczeń dokonanych przez A. Majcherczyka, odnośnie udziału osób z problemami związanymi z nadużywaniem substancji chemicznych $\mathrm{w}$ programach - jak to określił Autor - „szeroko rozumianej profilaktyki i terapii uzależnień", wynika, że bierze w nich udział najwyżej $20 \%$ potrzebujących ${ }^{24}$.

Wsparcie (support factors). Gotowość przestępcy do rozpoczęcia i pozostania $\mathrm{w}$ programie

może być funkcją stopnia dostępnego wsparcia. To wsparcie pochodzi od osób, które dobrze życzą przestępcy i chciałyby zobaczyć, jak z sukcesem przezwycięża swoje problemy. Chociaż członkowie rodziny i przyjaciele mogą zapewnić część tego wsparcia, to może nie wystarczyć dla pewnych osób. (...) duże znaczenie ma obecność pracowników więzienia, kuratorów i praktyków, którzy zachęcają przestępcę do rozpoczęcia konkretnego programu oraz dostarczają podstawowych faktów i wskazówek w tym zakresie ${ }^{25}$.

W środowisku taką rolę mogą odgrywać edukacja rówieśnicza czy mentoring, w celu poprawy poziomu wsparcia społecznego tak, aby zachęcić osoby do zaangażowania się i pozostania na terapii ${ }^{26}$.

Również to, co często określa się jako podejście instrumentalne/ motywacja instrumentalna, czyli chęć uzyskania nagrody za pomyślne ukończenie programu (np. warunkowe przedterminowe zwolnienie, przepustka) postrzegane jest jako ważny czynnik wspierający ${ }^{27}$.

${ }^{23}$ Zarządzenie nr 02/04 Dyrektora Generalnego Służby Więziennej z 24 lutego 2004 r. w sprawie szczegółowych zasad prowadzenia i organizacji pracy penitencjarnej oraz zakresów czynności funkcjonariuszy i pracowników działów penitencjarnych i terapeutycznych.

24 A. Majcherczyk, Programy resocjalizacyjne skazanych - głos w dyskusji o stanie i perspektywach więziennictwa, Przegląd Więziennictwa Polskiego, 2006, 52-53, s. 33.

25 T. Ward, A. Day, K. Howells, A. Birgden, The multifactor, s. 664.

${ }_{26}$ Zob. A. Barczykowska, S. Dzierzyńska, Zastosowanie mentoringu w działaniach profilaktycznych i resocjalizacyjnych (na przykładzie Stanów Zjednoczonych), Resocjalizacja Polska, 2012, 3, s. 263-276.

${ }^{27} \mathrm{~W}$ opracowanym przez J. Shaplanda i A. Bottomsa modelu odstąpienia od przestępczości, motywacja instrumentalna (spending years in prison is not in my best interests), obok motywa- 
Program/timing (Program/timing factors). Ostatnim zewnętrznym czynnikiem zidentyfikowanym w Wieloczynnikowym Modelu Gotowości Przestępcy jest czynnik, który można by określić mianem koordynacji. Jeżeli decyzja o szukaniu pomocy została już podjęta, przestępca musi uznać, że program stanowi właściwy sposób na otrzymanie pomocy. Ważnym wyznacznikiem tej decyzji będą postawy przestępcy wobec programów. Przestępca $\mathrm{w}$ tym momencie jest gotowy do pracy nad konkretnym problemem $\mathrm{w}$ czasie, który pasuje placówce, $\mathrm{z}$ odpowiednim terapeutą oraz $\mathrm{w}$ ramach określonego dostępnego i uważanego za odpowiedni programu. Alternatywnie, przestępca może posiadać wszystkie warunki osobiste, aby być gotowym do terapii i jest chętny rozpocząć program resocjalizacyjny, ale nie ten, nie $w$ tym momencie, bądź nie $z$ tym prowadzącym ${ }^{28}$.

\section{Zakończenie}

Wieloczynnikowy Model Gotowości Przestępcy nakreśla ramy, poprzez które można zidentyfikować czynniki wymagane do udanego zaangażowania się $\mathrm{w}$ program. Zgodnie $\mathrm{z}$ powyższym, zmiana przestępczego zachowania wymaga zaistnienia pewnych warunków wewnętrznych i zewnętrznych, stąd zwiększenie gotowości może nastąpić poprzez modyfikację samego podmiotu oddziaływań, programu, bądź warunków organizacyjnych/środowiska, $\mathrm{w}$ których jest on realizowany. W przypadku samego uczestnika programu, najistotniejszymi elementami modyfikującymi gotowość są te, które w polskiej literaturze określa się mianem komponentów postaw. Dlatego

$\mathrm{w}$ dziedzinie poznawczej pewien stopień rozpoznania problemu i decyzja o szukaniu pomocy są ważnymi czynnikami gotowości, wraz z zaufaniem do rodzajów programów i zapewnianych usług. $\mathrm{W}$ dziedzinie afektywnej pewien poziom ogólnego niepokoju (w tym lęku i depresji), poczucie winy lub wyrzuty sumienia są zidentyfikowane jako potencjalnie istotne czynniki gotowości, a w dziedzinie behawioralnej ważny wydaje się dostęp do wsparcia społecznego i pewna umiejętność funkcjonowania w grupie 29 .

Również sam program może być „nieprzygotowany” dla konkretnych grup przestępców, co wymaga odpowiedniego dopracowania. Łączy się to ze zmianą metody z uwagi na poziom umiejętności, czy płeć odbiorców

cji normatywnej (what kind of a person do I want to become?), znajduje swoje poczesne miejsce. J. Shapland, A. Bottoms, Reflections on social values, offending and desistance among young adult recidivists, Punishment \& Society, 2011, 13 (3), s. 256-282.

${ }^{28}$ T. Ward, A. Day, K. Howells, A. Birgden, The multifactor, s. 664-665.

29 Tamże, s. 666. 
programu, oraz jego strukturalnych składników, jak np. intensywność. Owa gotowość programu jest najbardziej podobna do zjawiska reaktywności, najwyraźniej zidentyfikowanego w modelu RNR D.A. Andrewsa i J. Bonta ${ }^{30}$. Ostatni czynnik można odnieść do środowiska i klimatu instytucji, w którym realizowany jest dany program. Te organizacyjno-społeczne kwestie, które L. Pytka definiuje jako

zbiór subiektywnie postrzeganych przez wychowanków i wychowawców charakterystycznych cech, sytuacji, zdarzeń, będących względnie trwałymi skutkami jego funkcjonowania $\mathrm{w}$ ramach przyjętego systemu organizacyjnego i pedagogicznego, kształtujący motywacje i zachowania jednostek i grup społecznych (...) instytucji31,

mogą w sposób zasadniczy obniżać gotowość jednostki do uczestnictwa w programie.

Jak wynika z Wieloczynnikowego Modelu Gotowości Przestępcy, zaproponowanego przez T. Warda i współautorów, gotowość ta ma szerszy zakres pojęciowy i jest bardziej złożonym terminem niż motywacja czy reaktywność. Ponadto, ma kluczowe znaczenie w skutecznej realizacji programów resocjalizacyjnych. Choć niska gotowość na wielu obszarach może skutkować nieukończeniem programu ${ }^{32}$ bądź brakiem wpływu na przyszłe zachowanie uczestników, to wysoki jej poziom nie przesądza jednoznacznie o dobrych wynikach. Decydujące znaczenie będzie miał tu sposób realizacji programu przez personel, umiejętność jego korygowania i reagowania na zmieniające się potrzeby przestępcy, uczestnika programu.

\section{BIBLIOGRAFIA}

Andrews D.A., Bonta J., The psychology of criminal conduct, 3rd edn, Cincinnati 2003.

Barczykowska A., Dzierzyńska S., Zastosowanie mentoringu w działaniach profilaktycznych i resocjalizacyjnych (na przykładzie Stanów Zjednoczonych), Resocjalizacja Polska, 2012, 3.

${ }^{30}$ Zob. np. D.A. Andrews, J. Bonta, The psychology of criminal conduct, Cincinnati 2003.

${ }^{31}$ L. Pytka, Pedagogika resocjalizacyjna, Warszawa 2000, s. 175; na temat klimatu społecznego instytucji resocjalizacyjnych zob. także S. Sobczak, Klimat społeczny instytucji resocjalizujących, Pedagogika Społeczna, 2007, 3, s. 133-152; A. Skuza, Klimat społeczny polskiego zakładu poprawczego (pedagogiczna analiza czynników kreujących), Resocjalizacja Polska, 2012, 3, s. 361-382.

32 Co w polskiej rzeczywistości, zwłaszcza penitencjarnej, jest sporadycznie spotykane? Najczęstsze powody nieukończenia programu czy terapii mają charakter organizacyjny i są związane z sądowym nakazem przetransportowania skazanego do innej jednostki, w związku z udziałem w czynnościach procesowych. W przypadku skazanych odbywających karę w systemie terapeutycznym, ponad 90\% kończy program - zob. K. Dubiel, A. Majcherczyk, Polski system terapii skazanych uzależnionych od narkotyków, Przegląd Więziennictwa Polskiego, 2006, 52-53, s. 57. 
Doliński D., Łukaszewski W., Typy motywacji, [w:] Psychologia. Podręcznik akademicki, t. I, red. J. Strelau, Gdańsk 2000.

Dubiel K., Majcherczyk A., Polski system terapii skazanych uzależnionych od narkotyków, Przegląd Więziennictwa Polskiego, 2006, 52-53.

Franken R.E., Psychologia motywacji, Gdańsk 2005.

Gierowski J.K., Jaśkiewicz-Obydzińska T., Najda M., Psychologia w postępowaniu karnym, Warszawa 2008.

Ginsburg J.I.D., Mann R.E., Rotgers F., Weekes J.R., Wywiad motywujacy z populacjami przestępczymi w trakcie odbywania kary lub dozoru, [w:] Wywiad motywujacy. Jak przygotować ludzi do zmiany, red. W.R. Miller, S. Rollnick, Kraków 2010.

Howells K., Day A., Readiness for anger management: clinical and theoretical issues, Clinical Psychology Review, 2003, 23 (2).

Howells K., Day A., Affective states in violent offenders and their relationship to readiness for treatment, International Journal of Offender Therapy and Comparative Criminology, 2006, 50 (2).

Howells K., Day A., Readiness for treatment in high risk offenders with personality disorders, Psychology, Crime \& Law, 2007, 13 (1).

Łukaszewski W., Motywacja w najważniejszych systemach teoretycznych, [w:] Psychologia. Podręcznik akademicki, t. I, red. J. Strelau, Gdańsk 2000.

Majcherczyk A., Programy resocjalizacyjne skazanych - głos w dyskusji o stanie i perspektywach więziennictwa, Przegląd Więziennictwa Polskiego, 2006, 52-53.

Majcherczyk A., Specyfika terapii uzależnienia od środków psychoaktywnych w zakładach karnych, Alkoholizm i Narkomania, 2007, 20, 3.

McGuire J., Motivation for what? Effective programmes for motivated offenders, [w:] Motivating Offenders to Change, a Guide to Enhancing Engagement in Therapy, red. M. McMurran, Chichester 2002.

Muskała M., Zakłady poprawcze readaptacyjne - nowa szansa readaptacji? Probacja, 2011, 2.

Prochaska J.O., Levesque D.A., Enhancing Motivation of Offenders at Each Stage of Change and Phase of Therapy, [w:] Motivating Offenders to Change, A Guide to Enhancing Engagement in Therapy, red. M. McMurran, Chichester 2002.

Pytka L., Pedagogika resocjalizująca, [w:] Encyklopedia pedagogiczna, red. W. Pomykało, Warszawa 1997.

Pytka L., Pedagogika resocjalizacyjna, Warszawa 2000.

Rheinberg F., Psychologia motywacji, Kraków 2006.

Rzońca I., Motywacja do aktywnego uczestnictwa w grze kierowniczej - wyniki badań ankietowych, Prace Naukowe Instytutu Organizacji i Zarządzania Politechniki Wrocławskiej, Studia i Materiały 2007, 25.

Serin R., Treatment responsivity, intervention and reintegration: a conceptual model, Forum on Corrections Research, 1998, 10 (1).

Serin R., Kennedy S., Treatment Readiness and Responsivity: Contributing to Effective Correctional Programming, Correctional Service of Canada 1997.

Shapland J., Bottoms A., Reflections on social values, offending and desistance among young adult recidivists, Punishment \& Society, 2011, 13 (3).

Skuza A., Klimat społeczny polskiego zakładu poprawczego (pedagogiczna analiza czynników kreujacych), Resocjalizacja Polska, 2012, 3.

Sobczak S., Klimat społeczny instytucji resocjalizujących, Pedagogika Społeczna, 2007, 3.

Ward T., Day A., Howells K., Birgden A., The multifactor offender readiness model, Aggression and Violent Behavior, 2004, 9 (6).

Wieczorkowska-Nejtardt G., Inteligencja motywacyjna, Warszawa 1998. 